\title{
股関節屈曲角度が棒体操時の 胸椎後彎角度に与える影響
}

\section{Effect of Hip Angle on Spinal Curvature during Rod Exercise}

\section{鈴木 哲 ${ }^{1)}$ 渡邊 進 ${ }^{2)}$}

TETSU SUZUKI, RPT ${ }^{1)}$, SUSUMU WATANABE, RPT ${ }^{2)}$

1) Department of Physical Therapy, Shimane Rehabilitation College: 1625-1 Minari, Okuizumo, Nita, Shimane 699-1511, Japan. TEL+81 854-54-0001 E-mail: su2uki0824@hi2.enjoy.ne.jp

${ }^{2)}$ Department of Rehabilitation, Faculty of Health Science and Technology, Kawasaki University of Medical Welfare

Rigakuryoho Kagaku 27(6): 641-644, 2012. Submitted May 23, 2012. Accepted Jul. 13, 2012.

ABSTRACT: [Purpose] We investigated the effect hip flexion angle has on spinal curvature during rod exercise. [Subjects] The subjects were 40 healthy adults aged $21.1 \pm 0.5$ years. [Methods] We measured thoracic kyphosis and lumbar lordosis angles in standing still (Condition A), as well as at hip flexion angles of $0^{\circ}$ (Condition B), 30 (Condition C), $60^{\circ}$ (Condition D), $90^{\circ}$ (Condition E), and $120^{\circ}$ (Condition F) during performance of the rod exercise, and compared the six conditions. [Results] Thoracic kyphosis in Condition A showed a significantly smaller value than those of all the other conditions, and was significantly smaller than Condition F in Condition B. Lumbar lordosis showed a significantly larger value in Condition $\mathrm{F}$ compared to all the other conditions, and showed a significantly smaller value than those of all the other conditions, except for Condition B, in Condition A. [Conclusion] Increasing the angle of hip flexion in the rod exercise can extend the thorax by restricting lumbar extension.

Key words: rod exercise, thoracic kyphosis angle, lumbar lordosis angle

要旨:〔目的〕股関節屈曲角度が棒体操時の胸椎後彎角度に与える影響を検討すること.〔対象〕健常成人 40 名（21.1 \pm 0.5 歳）とした。〔方法〕安静立位（条件 A）における胸椎後彎角度および腰椎前彎角度，および股関節屈曲角 $0^{\circ}$ (条件 B), $30^{\circ}$ (条件 C), $60^{\circ}$ (条件 D), $90^{\circ}$ (条件 E), $120^{\circ}$ (条件 F) における棒体操時の胸椎後彎角度および腰 椎後彎角度を測定し, 6 条件間で比較した。〔結果〕条件 A の胸椎後彎角度はその他の条件と比べ, 条件 B は条件 F と比べ有意に小さい值を示した，条件 F の腰椎前彎角度はその他の条件と比べ有意に大きい值を示し，条件 A は条 件 B を除くその他の条件と比べ有意に小さい值を示した。〔結語〕棒体操時に股関節屈曲角度を増加させることによ り, 腰椎の伸展を抑制した状態で胸椎を伸展できる. キーワード : 棒体操, 胸椎後彎角度, 腰椎前彎角度

\footnotetext{
1) 島根リハビリテーション学院＼cjkstart理学療法学科:島根県仁多郡奥出雲町三成 1625-1 († 699-1511) TEL 0854-54-0001

2)川崎医療福祉大学 医療技術学部 リハビリテーション学科 


\section{I.はじめに}

胸椎後彎角度は年齢とともに増加する傾向にあり，高 齢者において過剩な胸椎の後彎，いわゆる胸椎後彎変形 は頻繁にみられる1)。胸椎後彎変形をしたものの中には 胸椎後彎角度の増大を腰椎の前彎角度を増すことで代償 する姿勢である円凹背姿勢をとるものも多く，このよう なものでは椎間関節症を引き起こす可能性が高い2,3). 加えて, 胸椎後彎角度の増加は, Activities of Daily Living（ADL）の低下や, 転倒発生率および死亡率の増 加に関与している可能性が示唆されている4-8)。 そのた め胸椎後彎変形を改善もしくは予防することが重要であ る.

胸椎後彎変形の改善を目的とした介入の一つに棒体操 がある9)、棒体操は，両上肢で棒を挙上するセルフエク ササイズで, 上肢の拳上最終域付近で生じる胸椎抢よび 腰椎の伸展運動を利用するものである ${ }^{10,11)}$.上田ら ${ }^{12)}$ は， 片側上肢拳上 $150^{\circ}$ から胸椎後彎角度の減少が生じると 報告している.Kapandji ${ }^{13)}$ は両上肢拳上角度 $120^{\circ}$ より 腰椎の伸展が生じると述べている。また棒体操は立位や 座位など様々な股関節屈曲角度で実施されている。一般 に立位に比べ座位では腰椎は後彎位をとる. Keegan ら 14)は, 詳細な数值を記したデータではないが, 股関節 屈曲角度が大きくなればなるほど骨盤後傾拉よび腰椎前 彎の減少が起こることを報告. この理由の一つとして股 関節屈曲角度の増大に伴う八ムストリングスなど大腿後 面の筋群の伸張されることを挙げている。 また立位と違 い座位では上半身の重さは支点になっている坐骨より後 方にかかるため, 重力により骨盤後傾抢よび腰椎後彎を 促す力が働く ${ }^{15)}$ ，そのため棒体操時の股関節屈曲角度 を大きくすることで腰椎の伸展を抑制し, 脊椎にかかる 伸展ストレスをより胸椎にかけることができる可能性が ある. しかし, 股関節屈曲角度の変化が棒体操時の胸椎 後彎角度抢よび腰椎前彎角度に与える影響を検討した報 告は見当たらず，未だ明確でない。

そこで本研究では, 安静立位における胸椎後彎角度お よび腰椎前彎角度, および股関節屈曲角 $0^{\circ}, 30^{\circ}, 60^{\circ}$, $90^{\circ}, 120^{\circ}$ に扔ける棒体操時の胸椎後彎角度拧よび腰椎 前彎角度を測定し比較することで, 股関節屈曲角度の変 化が棒体操時の胸椎後彎角度掞よび腰椎前彎角度に与え る影響を検討した。

\section{II. 対象と方法}

\section{1. 対象}

対象は男性20名 (年齢: $21.3 \pm 0.5$ 歳身長: $171.5 \pm 8.2 \mathrm{~cm}$ 体重：68.4 $\pm 10.7 \mathrm{~kg}$ ), 女性 20 名（年齢：21.0 \pm 0.9 歳 身長 : $159.8 \pm 5.8 \mathrm{~cm}$ 体重 : $50.9 \pm 3.1 \mathrm{~kg}$ ) とした，事前 に, 過去 3 个月以内の腰痛既往者, 神経学的徴候のある
もの, 体幹屈曲・伸展の可動域制限があるものはいない ことを確認した。また測定中に腰部もしくは下肢に疼痛 や不快感を生じた場合は，測定を中止することとした， すべての対象者は参加の際に, 研究の趣旨・方法・リス クを説明し，文書にて同意を得た，加えて島根リハビリ テーション学院の倫理審査委員会の承認を得た（承認番 号: 6).

2. 方法

安静立位（条件A）における胸椎後彎角度および腰椎 前彎角度, 抒上び股関節屈曲角度 $0^{\circ}$ (条件 $\left.\mathrm{B}\right), 30^{\circ}$ (条 件 C), $60^{\circ}$ (条件 $\left.\mathrm{D}\right), 90^{\circ}$ (条件 $\mathrm{E}$ ), $120^{\circ}$ (条件 F) に押 ける棒拳上時の胸椎後彎角度掞よび腰椎前彎角度を測定 した。

胸椎後彎角度㧍よび腰椎前彎角度の測定は, 先行研 究16)を参考に実施した。測定機器は, Index社製の Spinal Mouseを使用した。このSpinal Mouseは非侵襲 的かつ比較的容易に脊柱の彎曲角度を被験者背部の体表 面から測定でき，その高い信頼性も報告されている ${ }^{17) .}$ 条件ごとに第 7 頸椎から第 3 仙椎までの脊椎傍線上を Spinal Mouse を頭側から尾側へ移動させて測定した。 ま た条件ごとに測定は 3 回実施した。その後, 対象者ごと に第 1 胸椎から第 12 胸椎までの上下椎体間がな寸角度 の総和である胸椎後彎角度と, 第 1 腰椎から第 1 仙椎ま での上下椎体間がなす角度の総和である腰椎前彎角度の 平均值を算出し，以後のデータとして使用した。胸椎後

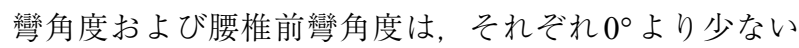
と前彎を, $0^{\circ}$ より大きいと後彎を示す。

条件C-Eで対象者が座る台は昇降式のプラットフォー

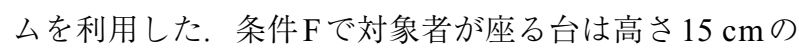
台と微調整のための数枚の厚紙を使用した. 拳上する棒 は直径 $4 \mathrm{~cm}$, 長さ $100 \mathrm{~cm}$ の木製のものを使用した，事 前に対象者に, 棒は前腕回内位で把持しするように指導 した。ささらに棒を把持する位置は左右の肩峰より $15 \mathrm{~cm}$ 外側とした。両条件ともに $2 \mathrm{~m}$ 離れた目線レベルの目的 物を注視させた，その後各条件で両上肢にて棒を肩屈曲 $180^{\circ}$ まで拳上させ，その際の胸椎後彎角度捛よび腰椎 前彎角度を測定した。条件C-Fに打兴股関節屈曲角度 および各条件に打ける肩屈曲角度は, 日本リハビリテー ション医学会評価基準委員会の基準に従い理学療法士が ゴニオメーターを使用して規定した。測定の順番は条件 Aから始めることとした，その後の順番はくじを引かせ て決定した。 くじはB-C-D-E-Fの順, C-D-E-F-B の順, D-E-F-B-Cの順, E-F-B-C-D の順, F-B-C-D-Eの順の 5 種類を男女ごとに各4枚作成し, 条件 B-Fに打いて特定 の条件の測定順番が早くなる等の偏りが出ないようにし た.

統計処理には，SPSS（ver.16）を使用した。各条件間 の胸椎後彎角度および腰椎前彎角度の大きさを, 一元配 
表 1 安静立位および 5 種類の股関節屈曲角度で両上肢にて棒を拳上した際の胸椎後彎角度の大きさの比較 $(\mathrm{n}=40)$

\begin{tabular}{lcccccc}
\hline & 条件 $\mathrm{A}$ & 条件 $\mathrm{B}$ & 条件 $\mathrm{C}$ & 条件 $\mathrm{D}$ & 条件 $\mathrm{E}$ & 条件 $\mathrm{F}$ \\
\hline 胸椎後彎角度 & $29.3 \pm 9.3$ & $18.3 \pm 10.6 *$ & $14.0 \pm 9.2 *$ & $15.6 \pm 10.1 *$ & $13.9 \pm 10.4 *$ & $11.4 \pm 9.1 * \dagger$ \\
\hline *: 条件 $\mathrm{A}$ と比べ有意差有り & $\dagger:$ 条件 $\mathrm{B}$ と比べ有意差有り & & & &
\end{tabular}

表 2 安静立位および 5 種類の股関節屈曲角度で両上肢にて棒を拳上した際の腰椎前彎角度の大きさの比較 $(\mathrm{n}=40)$

\begin{tabular}{|c|c|c|c|c|c|c|}
\hline & 条件 A & 条件 B & 条件 C & 条件 D & 条件 E & 条件 F \\
\hline 腰椎前彎角度 & $-18.8 \pm 7.9$ & $-23.3 \pm 8.8 *$ & $-2.0 \pm 13.3 * \dagger \hbar$ & $-4.0 \pm 12.7 * \dagger \hbar$ & $-5.3 \pm 11.1 * \dagger t$ & $7.2 \pm 13.1 * \dagger$ \\
\hline
\end{tabular}

置分散分析 (ANOVA) を使用し比較した。有意差が得ら れた場合にはTukeyのHSDを用いて事後検定を行った。 それぞれ有意水準は $5 \%$ 未満とした。

\section{III. 結 果}

条件 $\mathrm{A}$ の胸椎後彎角度は, その他の条件と比べ, 有意 に大きい值を示した。また条件 $\mathrm{F}$ の胸椎後彎角度は, 条 件 Bと比べ，有意に小さい值を示した。その他の条件間 で有意な差は見られなかった（表1）.

条件 $\mathrm{A}$ の腰椎前彎角度は, 条件 $\mathrm{C}, \mathrm{D}, \mathrm{E}, \mathrm{F}$ と比べ, 有意に小さい值を示したが，条件 $\mathrm{B}$ との間に有意な差は 見られなかった。また，条件 C, D, E, Fの腰椎前彎角 度は，条件 Bと比べて，有意に大きい值を示した。さら に条件 $\mathrm{F}$ の腰椎前彎角度は, 条件 $\mathrm{C}, \mathrm{D}, \mathrm{E}$ と比べ有意 に大きい值を示した。条件 $\mathrm{C}, \mathrm{D}, \mathrm{E}$ 間で有意な差は見 られなかった(表2).

\section{IV. 考 察}

本研究では, 安静立位時の胸椎後彎角度および腰椎前 彎角度, おょび股関節屈曲角度 $0^{\circ}, 30^{\circ}, 60^{\circ}, 90^{\circ}$, $120^{\circ}$ における棒体操時の胸椎後彎角度および腰椎前彎 角度を比較した。

その結果, 棒を拳上したすべての条件における胸椎後 彎角度は安静立位と比べて有意に小さい值を示した。ま た股関節屈曲角度 $120^{\circ}$ で棒を拳上した際の胸椎後彎角 度は, 股関節屈曲角度 $0^{\circ}$ と比べて, 有意に小さい值を 示した。腰椎前彎角度は, 股関節屈曲角度 $0^{\circ}$ の条件を 除き, 安静立位と比べ，その他の条件すべてにおいて有

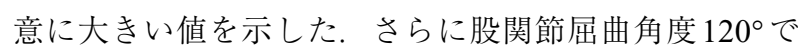
棒を拳上した際の腰椎前彎角度はその他のすべての条件 と比べ有意に大きい值を示した。 以上から棒拳上時に股 関節屈曲角度を増加させることにより, 腰椎の伸展を抑 制した状態で胸椎を伸展できることが示された。加えて 股関節屈曲角度 $120^{\circ}$ で棒を拳上することにより, 股関
節屈曲角度 0 ○で棒拳上を行った時と比べて, より胸椎 を伸展できることが示された。

一般に股関節屈曲角度 $0 \circ$ の状態で棒拳上を行うと胸 椎および腰椎が伸展される12,13). しかし股関節屈曲角 度 $0^{\circ}$ り股関節屈曲角度が増加されることにより，八 ムストリングスなど大腿後面の筋群が伸長され，骨盤後 傾および腰椎後彎化が促される ${ }^{14)}$. 加えて立位と違い 座位では上半身の重さは支点になっている坐骨より後方 にかかるため, 重力により骨盤後傾および腰椎後彎を促 す力が働く15). これらのことから股関節屈曲角度を増 加させることにより腰椎の伸展を抑制することができ, 両上肢にて棒を拳上した際の脊椎にかかる伸展方向への ストレスをより胸椎にかけることができたのではないか と考えた。

また股関節屈曲角度 $30^{\circ}$ で棒を拳上した際の胸椎後彎 角度は, 有意差は無いものの, 股関節屈曲角度 $60^{\circ}$ お び $90^{\circ} の$ 条件と比べ, 腰椎は後彎する傾向を示した．股 関節屈曲角度 $30^{\circ}$ の座位では, 股関節屈曲角度 $60^{\circ}$ お び $90^{\circ} の$ 条件と比べ膝が伸展位となる。 そのためハムス トリングスなど大腿後面の筋群が伸長され, 骨盤後傾お よび腰椎後彎化が促されたのではないかと考える.

臨床において，椎間関節症など腰椎伸展ストレスで腰 痛が増強するような患者に対し, 胸椎後彎変形の改善を 目的とした棒体操を立位で実施すれば，更なる腰椎伸展 ストレスを加えることになるため，適用できないことが 多い.このような患者に対しては, 股関節屈曲角度を増 加させた状態で棒体操を行うことにより, 腰椎伸展ス卜 レスを軽減しつつ脊椎にかかる伸展方向へのストレスを より胸椎にかけることができ, 有用となる可能性がある.

本研究の対象者は健常成人であるため, 今後は胸椎伸 展可動域の低下した高齢者や腰椎の伸展ストレスにより 腰痛が増強するものを対象に検討する必要がある。肩甲 上腕関節の可動域が低下している高齢者などでは，両上 肢の過度な拳上により肩甲上腕関節の疼痛を生じさせる 可能性があるため, 本研究結果をそのまま臨床適用する 際には注意が必要であると考えられる。また股関節屈曲 
角度が棒拳上時の体幹筋活動に与える影響を検討してい ない．股関節屈曲角度を増すとともに棒を拳上するため の筋活動が増加している可能性もある。これらは今後の 課題としたい.

\section{引用文献}

1) Fon GT, Pitt MJ, Thies AC: Thoracic kyphosis: range in normal subjects. AJR, 1980, 134(5): 979-983.

2) 竹光義治, 加茂裕樹, 熱田裕司 - 他 : 高齢者の各種脊柱後 彎と腰痛. 整·災外, 1993，36(8): 901-907.

3) 城由紀子, 青木一治, 友田淳雄: 腰椎椎間関節症患者の 脊柱アライメントと腰痛の関係. 理学療法科学, 2009, 24(1): 65-69.

4) Kado DM, Huang MH, Barrett-Connor E, et al.: Hyperkyphotic posture and poor physical functional ability in older community-dwelling men and women: the Rancho Bernardo study. J Gerontol A Biol Sci Med Sci, 2005, 60(5): 633-637.

5) Sinaki M, Bery RH, Hughes CA, et al.: Balance disorder and increased risk of falls in osteoporosis and kyphosis: significance of kyphotic posture and muscle strength. Osteoporos Int, 2005, 16(8): 1004-1010.

6) Harrison RA, Siminoski K, Vethanayagam D, et al.: Osteoporosis-related kyphosis and impairments in pulmonary function: a systematic review. J Bone Miner Res, 2007, 22(3): 447-57.

7) Kado DM, Huang MH, Nguyen CB, et al.: Hyperkyphotic posture predicts mortality in older community-dwelling men and women: a prospective study. J Am Geriatr Soc, 2004, 52(10): 1662-1667.

8) Glassman SD, Bridwell K, Dimar JR, et al.: The impact of positive sagital balance inadult spinal deformity. Spine, 2005, 30(18): 2024-29.

9) Bautmans I, Van Arken J, Van Mackelenberg M, et al.: Rehabilitation using manual mobilization for thoracic kyphosis in elderly postmenopausal patients. J Rehabil Med, 2010, 42(2): 129-135.

10) Lanz TV, Wachsmuth W: Praktische anatomie, Arm. Verlag von Julius Springer, Berlin, 1935, pp49-107.

11) Crosbie J, Kilbreath SL, Hollmann L, et al.: Scapulohumeral rhythm and associated spinal motion. Clin Biomech, 2008, 23(2): 184-192.

12）上田泰之, 浦辺幸夫, 大林弘宗・他：若年者と高齢者に おける上肢拳上時の体幹アライメントの違い. 体力科学, 2008, 57(4): 485-490.

13) Kapandji IA: The physiology of the joints 1, Churchill Livingstone, New York, 1982, 1-71.

14) Keegan JJ: Alterations of the lumbar curve related to posture and seating. J Bone Joint Surg, 1953, 35A(3): 589-603.

15) 中村隆一：臨床運動学 第 3 版, 医歯薬出版, 東京, 2003, pp410-413.

16) 鈴木 哲, 平田淳也, 大槻桂右：膝当てを取り付けた前傾 座面椅子と従来の椅子間に扔ける座位時の体幹筋活動と脊 椎カーブの比較. 理学療法科学, 2011, 26(2): 263-267.

17) Post RB, Leferink VJM: Spinal mobility: sagittal range of motion measured with the Spinal Mouse, a new non-invasive device. Arch Orthop Trauma Surg, 2004, 124(3): 187-192. 